\title{
A new isolate of Melolontha melolontha entomopoxvirus in Turkey: Morphology, infectivity and prevalence in the field
}

\author{
Kazim SEZEN* and Zihni DeMIRBAG \\ Department of Biology, Faculty of Arts and Sciences, Karadeniz Technical University; Trabzon 61080, Turkey
}

(Received 2 August 2004; Accepted 28 April 2006)

\begin{abstract}
A virus infection caused by Melolontha melolontha L. (Coleoptera: Scarabaeidae) entomopoxvirus (MmEPV) was recorded in $0.87 \%$ of 1,260 larvae collected in 2001-2002 in Trabzon, Turkey. The diseased larvae had dark brown or black and white spots, compared to the normal white-cream colour of healthy larvae. MmEPV infections reduced the larval life span from 6 mo to $15 \pm 5 \mathrm{~d}$ (Mean \pm S.D.). Based on light and electron microscopic observations, the average length of the spheroids was $5.45 \pm 2.34 \mu \mathrm{m}$ (Mean \pm S.D.) and the average width was $2.89 \pm 1.13 \mu \mathrm{m}$ (Mean \pm S.D.) $(n=50)$. The presence of a virus was also demonstrated in a DNA-DNA hybridization assay. The bioassays carried out to determine the infectivity of MmEPV proved its effectiveness against the third-instar larvae of the $M$. melolontha. The highest insecticidal activity determined in the M. melolontha larvae was $93.3 \%$ at the concentration of $7.5 \times 10^{6}$ spheroids/ml. Our results suggest that a Turkish isolate of MmEPV is promising for biological control of the $M$. melolontha larvae.
\end{abstract}

Key words: Biological control; entomopoxvirus; Melolontha melolontha; insect virus

\section{INTRODUCTION}

The Melolontha melolontha entomopoxvirus (MmEPV) was the first poxvirus to be described as associated with an insect disease (Vago, 1963). Since then, many entomopoxviruses (EPVs) have been found, infecting Coleoptera, Lepidoptera, Diptera, Hymenoptera, and Orthoptera (Goodwin et al., 1991; Arif, 1995). Twenty EPV strains were recorded in Scarabaeidae (Glare and Jackson, 1992; King et al., 1998). The virus described below is the first isolate of the MmEPV found in Turkey and the second in the world.

In the late stage of EPV infection, the virions are generally occluded into a paracrystalline proteinaceous matrix giving rise to large oval-shaped or paraspherical occlusion bodies originally designated as "spherules" (spheroids) in the MmEPV infection (Bergoin et al., 1969). Once released from cadavers, the spheroids ensure the survival of the virions during the extracellular phase of their lifecycle, thus allowing the natural prevalence of the disease. In this respect, the EPV occlusion bodies fulfill the same functions as those of the polyhedra or capsules of baculoviruses (Bilimoria, 1991) or the polyhedra of cypoviruses (Hukuhara and Bonami, 1991). A salient feature of several EPV infections, including those of Coleoptera and of some Lepidoptera, is the presence of a second type of cytoplasmic spindle-shaped inclusion. These cytoplasmic paracrystalline inclusions are named "spindles". Unlike the spheroids, the spindles are devoid of virions. The gene coding for fusolin (fus gene) that forms the spindle was identified by Bergoin et al. (1970).

M. melolontha L. (Coleoptera: Scarabaeidae) is one of the most important pests of hazelnuts in Turkey. At present, chemical pesticides are used to control this pest in Turkey, but they have hazardous effects on the environment. Recent concerns about both the hazardous effects and the inadequacy of the chemical pesticides in the environment have encouraged a number of scientists to search for more effective and safer control agents. A French isolate of MmEPV was studied in detail in Europe (Bergoin et al., 1969, 1970, 1971; Sanz et al.,

* To whom correspondence should be addressed at: E-mail: sezen@ktu.edu.tr DOI: $10.1303 /$ aez.2006.471 
1994; Arif, 1995; Gauthier et al., 1995). Since Turkey acts as a bridge connecting Asia and Europe, the study of a Turkish isolate of the $M$. melolontha EPV is of great importance. In this study, a Turkish isolate of MmEPV was characterized and its biological characteristics were determined.

\section{MATERIALS AND METHODS}

Insect collection. Melolontha melolontha larvae showing the signs of viral infection (Evans and Shapiro, 1997), and healthy larvae were collected during 2001-2002 from hazelnut fields in the vicinity of Trabzon (Northern Turkey) in order to investigate a viral infection. The larvae were brought to the laboratory and placed individually in bottles.

Microscopic observations. Of body fat and hemocytes taken from the diseased and dead larvae and examined under a microscope (Nikon Phase Contrast Eclipse E600), some samples showed a large number of spheroids. After the microscopic observation, a thin smear of infected tissue was made on a microscope slide and stained for $45 \mathrm{~min}$ in $10 \%$ Giemsa in $0.02 \mathrm{M}$ phosphate buffer and 5 min in Buffalo Black 12 B. After staining, the spheroids were examined under an oil immersion objective. The spheroids were also studied under a transmission electron microscope (TEM) (Philips JM 208) (Radek and Fabel, 2000). To determine the virion number in a spheroid, 50 randomly selected spheroids were counted under TEM.

Purification of spheroids. A stock of MmEPV was obtained by infecting $M$. melolontha larvae with inocula extracted from the field-collected and infected larvae and stored at $-20^{\circ} \mathrm{C}$ until use (Sezen, 2004). The larval tissues were homogenized with $0.1 \mathrm{M}$ Tris- $\mathrm{HCl}(\mathrm{pH} 7)$ containing $0.01 \%$ SDS. The homogenate was frozen, thawed, and passed through cheesecloth. The spheroids were pelleted at $1,000 \times g$ for $10 \mathrm{~min}$, resuspended in the sterile water, layered on a $40-65 \%(\mathrm{w} / \mathrm{w})$ continuous sucrose gradient, and then centrifuged at $16,000 \times g$ for $30 \mathrm{~min}$ (Beckman Optima LE-80K Ultracentrifuge, SW40Ti Rotor, $5^{\circ} \mathrm{C}$ ). The band containing spheroids was recovered, diluted with water, pelleted, resuspended in water, and stored at $-20^{\circ} \mathrm{C}$ (Hernandez-Crespo et al., 2000).

DNA extraction. The purified spheroids were dissolved in $0.2 \mathrm{M}$ sodium thioglycollate and $0.2 \mathrm{M}$ sodium carbonate, $\mathrm{pH} 10.9$, for about $30 \mathrm{~min}$. An equal volume of $1 \mathrm{M}$ Tris-HCl ( $\mathrm{pH} 7)$ was added. The virus suspension was treated with the proteinase $\mathrm{K}(500 \mu \mathrm{g} / \mathrm{ml})$ and $2 \%$ sarcosyl at $45^{\circ} \mathrm{C}$ overnight. Sodium and cetyltrimethylammonium bromide were then added to the final concentrations of $0.5 \mathrm{M}$ and $0.015 \%$, respectively, and incubation was continued at $60^{\circ} \mathrm{C}$ for $1 \mathrm{~h}$. The viral DNA was extracted twice with phenol, and once each with phenol:chloroform and chloroform (Hernandez-Crespo et al., 2000).

Preparation of a DNA probe. A gene-specific probe was obtained by digesting pUC19 plasmid containing the fus gene of Choristoneura fumiferana (Lepidoptera: Tortricidae) EPV (CfEPV) with EcoRI. The digest was analyzed by $0.7 \%$ agarose gel electrophoresis in TAE $(0.04 \mathrm{M}$ Tris-acetate, $0.001 \mathrm{M}$ EDTA pH 8.0) buffer, containing ethidium bromide. After separation, the fragment was purified after the separation by the electrophoresis and eluted with a GeneClean Kit (Qiagen, Hilden, Germany), and the probes were labeled using the DIG High Prime DNA Labeling and Detection Starter Kit I (Roche Diagnostics GmbH, Germany).

DNA-DNA hybridization assay. Using a slotblot apparatus (Hoefer Scientific Instruments) the DNAs $(10 \mu \mathrm{g})$ were vacuum-blotted onto a nylon membrane. Prehybridization and hybridization were carried out following the supplier's protocols (Roche Diagnostics) using the DIG High Prime DNA Labeling and Detection Starter Kit I (for color detection with NBT/BCIP). All experiments in the study included a positive and negative control; the positive control was the DNA from CfEPV, and the negative control was the DNA from uninfected M. melolontha larvae.

Infectivity of MmEPV. An artificial diet was prepared from the roots of Corylus sp. and collected field soil, which was then sterilized. The diet was placed in glass containers $(80 \mathrm{~mm}$ in diameter). One milliliter of suspension containing purified spheroids was applied to the diet surface. For each infectivity test, 10 third-instar larvae were placed on the diet in the containers, and kept at $26 \pm 2{ }^{\circ} \mathrm{C}$ (S.D.) and $60 \% \mathrm{RH}$ with a change of diet every $5 \mathrm{~d}$ (Lipa et al., 1994). The larval mortality was recorded every $24 \mathrm{~h}$, and all the dead larvae were removed from the containers. All the bioassays were repeated three times on different occa- 
sions.

Pathogenicity of MmEPV. The purified spheroids were used for inoculation to $M$. melolontha larvae collected from hazelnut fields for each assay. The concentration of MmEPV spheroids was determined with a hemacytometer, and the suspensions containing $7.5 \times 10^{6}, 1.5 \times 10^{4}$ and $1 \times 10^{2}$ spheroids $/ \mathrm{ml}$ ( $1 \mathrm{ml}$ of each suspension for 10 larvae) were administrated as described above. All the bioassays were repeated three times on different occasions.

Effect of temperature on MmEPV infection. To determine the optimum infection temperature, $7.5 \times 10^{6}$ spheroids/ml MmEPV (for 10 larvae) was used for the inoculation as described above, at 20, $22,25,28$ and $30^{\circ} \mathrm{C}$. After the infection period $(5 \mathrm{~d})$, the rearing temperature was adjusted to $26 \pm 2{ }^{\circ} \mathrm{C}$ (S.D.). Thirty larvae were used for each temperature. All the bioassays were repeated three times on different occasions.

Horizontal infection of the MmEPV. Three experimental groups were set up to determine the horizontal infection of MmEPV. The first group included 30 third-instar larvae fed on the MmEPVcontaminated $\left(7.5 \times 10^{6}\right.$ spheroids $\left./ \mathrm{ml}\right)$ diet. The second group was set up in the same way as the first group, but at $7 \mathrm{~d}$ post-treatment, 30 healthy larvae were added to this group after removing the contaminated diet. In this group, a total of 60 larvae (infected+uninfected) were fed on the uncontaminated diet for $40 \mathrm{~d}$. The third group consisted of 30 healthy larvae fed on the uncontaminated diet. All the bioassays were repeated three times on different occasions.

\section{RESULTS AND DISCUSSION}

\section{Entomopoxvirus occurrence}

As shown in Table 1, the infection caused by MmEPV was first recorded in one of 128 Melolontha melolontha larvae collected in February 2001 in the vicinity of Trabzon, Turkey. Due to the cold weather, no infection was observed among the 215 larvae collected in December (mean $8^{\circ} \mathrm{C}$ ) and January (mean $5^{\circ} \mathrm{C}$ ) $2001-2002$. When the collecting period was extended to the middle of February, a low level of MmEPV infection was recorded. During March and April, the infection level reached a maximum of $1.3 \%$. At the end of April and later, the infection level of MmEPV decreased. The 121
Table 1. Proportion of EPV infection in diseased $M$. melolontha larvae collected in the vicinity of Trabzon, Turkey during 2001-2002

\begin{tabular}{lccl}
\hline Collection & $\begin{array}{c}\text { Diseased } \\
\text { larvae }\end{array}$ & $\begin{array}{c}\text { EPV-infected } \\
\text { larvae }\end{array}$ & $\begin{array}{c}\text { \% of EPV } \\
\text { infection }\end{array}$ \\
\hline Jan. 2001 & 133 & - & 0 \\
Feb. 2001 & 128 & 1 & 0.78 \\
Mar. 2001 & 156 & 2 & 1.28 \\
Apr. 2001 & 164 & 2 & 1.22 \\
May 2001 & 121 & 1 & 0.83 \\
Dec. 2001 & 55 & - & 0 \\
Jan. 2002 & 27 & - & 0 \\
Feb. 2002 & 117 & 1 & 0.85 \\
Mar. 2002 & 162 & 2 & 1.23 \\
Apr. 2002 & 83 & 1 & 1.2 \\
May 2002 & 114 & 1 & 0.88 \\
\hline
\end{tabular}

larvae collected in May 2001 and 114 in May 2002 were infected at a level of 0.826 and $0.877 \%$, respectively. We collected a total of $1,260 \mathrm{M}$. melolontha larvae in 2001 and 2002, and the infection level of MmEPV in this period was $0.87 \%$.

Our results indicate that MmEPV infection occurred at a low level during surveying seasons. Generally, the coleopteran infections in nature are found at a low level. Milner and Lutton (1975) determined that $2.2 \%$ of Othnonius batesi in a natural population exhibited the symptoms of virus infection. Wegensteiner and Weiser (1995) reported that the Ips typographus (Coleoptera: Scolytidae) EPV (ItEPV) was present only in $0.3 \%$ of larvae $(n=$ 886).

\section{Light microscopy}

The spheroids were stained blue by Giemsa and black by Buffalo Black 12 B (data not shown). The spheroids were oval and measured $5.45 \pm 2.34 \mu \mathrm{m}$ (Mean \pm S.D.) in length and $2.89 \pm 1.13 \mu \mathrm{m}$ (Mean \pm S.D.) in width $(n=50)$. The length of spheroids in insect poxviruses ranges from 1 (Amsacta moorei EPV) to $25 \mu \mathrm{m}$ (Phyllopertha horticola EPV) (Granados, 1973). Arif (1991) reported that the length of MmEPV spheroids is $10-24 \mu \mathrm{m}$. There are some differences between the lengths of the Turkish and French isolates. The spheroids of Turkish isolate were considerably smaller than those of French isolate although their minimum and maximum size ranges overlap. 


\section{Electron microscopy}

Figure 1a illustrates a thin section of MmEPV spheroids. The average number of virions occluded per spheroid was $16 \pm 4$ (Mean \pm S.D.) $(n=50)$. The folds in the outer envelope produce the beaded appearance typical of EPVs. In Fig. 1b, a longitudinal section through the virus core shows the unilaterally concave shape common to the EPVs in genus A. The virions were ovoid in appearance, with a
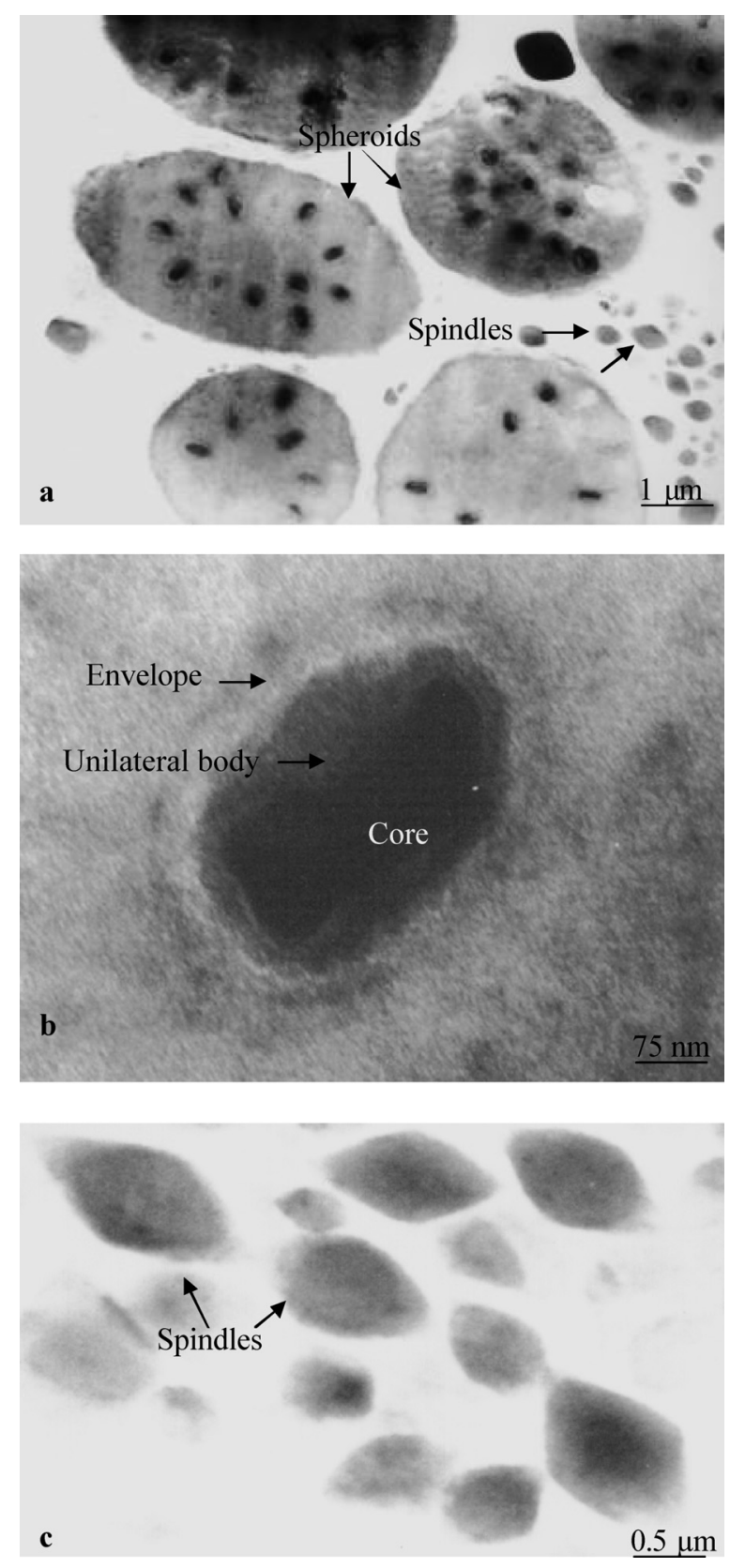

Fig. 1. Transmission electron micrographs of MmEPV. a) Structure of spheroid and spindle; b) Fine structure of occluded virion; c) Structure of spindles. length of $450 \mathrm{~nm}$ and width of $260 \mathrm{~nm}$. The average length of spindles was determined as $1.071 \pm 1.186 \mu \mathrm{m}$ (Mean \pm S.D.) (Fig. 1c). The minimum and maximum lengths of spindles in the MmEPV Turkish isolate were 0.22 and $4.4 \mu \mathrm{m}$, respectively. Spindles can vary a great deal in size, even within the same species, from 0.5 to $12 \mu \mathrm{m}$ (Vago and Bergoin, 1968).

\section{Slot-blot hybridization}

The viral infection of $M$. melolontha was also demonstrated by the DNA-DNA hybridization. The experiment was designed to confirm that the larvae were infected with an EPV. The hybridization assay showed that the CfEPV fus probe hybridized with DNA extracted from EPV spheroids of common cockchafer larvae and CfEPV DNA (positive control). Hybridization was not observed between the probe and DNA from the uninfected larvae (negative control) (Fig. 2). These results also indicate that the isolated agent was an EPV. There was DNA sequence homology between the CfEPV and MmEPV Turkish isolate. However, the degree of homology was lower between the CfEPV and MmEPV French isolate. Gauthier et al. (1995) compared the amino acid sequence of MmEPV (French isolate) fusolin with the NBRF data library. This study revealed $51 \%$ identity to the CbEPV and HsEPV fusolin polypeptides.

\section{Pathogenicity of MmEPV on M. melolontha lar- vae}

The experimental infections in the laboratory indicated that the MmEPV has infectivity against the third-instar M. melolontha larvae. The MmEPV infection reduced the larval life span from 6 mo to $15 \pm 5 \mathrm{~d}$ (Mean \pm S.D.) in laboratory conditions. The

\section{MmEPV DNA Cf EPV fus gene Uninfected Mm DNA}

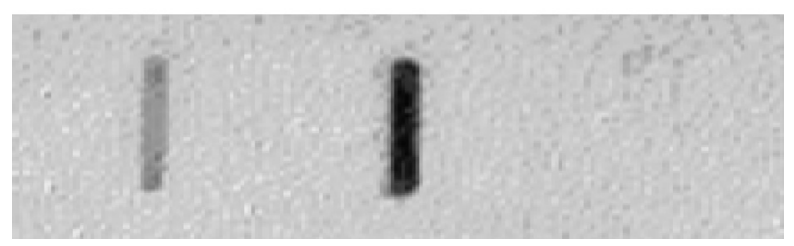

Fig. 2. Determination of viral DNA infected M. melolontha larvae. Slot-blot hybridization of MmEPV DNA (DNA extracted from purified OBs), CfEPV fus gene (positive control) and Mm DNA (DNA extracted from uninfected M. melolontha larvae, negative control) with a CfEPV fus gene probe. All DNA samples were $10 \mu \mathrm{g} / \mathrm{slot}$. 
previous studies show that the survival time of EPV-infected insects varies considerably, from 20 to $60 \mathrm{~d}$ (Jaeger and Langridge, 1984). The symptoms of the disease vary among hosts. In some hosts, the larvae show little sign until late in the infection, when motility and coordination are adversely affected. The majority of virus replication and the formation of occlusion bodies appear to take place in the fat body tissues between 8 and $10 \mathrm{~d}$ post-infection; however, this can vary from species to species. Also, the infection period can be very long (up to $40 \mathrm{wk}$ ) (King et al., 1998). Hurpin (1968) determined that the infection time of the French isolate of MmEPV may require a long period, up to $8-13 \mathrm{wk}$, on the M. melolontha larvae. The same study shows that B. popilliae subsp. melolonthae and Rickettsiella melolonthae have an $\mathrm{LT}_{50}$ of 7-9 and 5 wk on M. melolontha larvae, respectively. MmEPV-infected larvae change colour from white-cream to dark brown and black with the hemolymph becoming whitish-blue, possibly because of the accumulation of the spheroid occlusion bodies. It is reported that the Estigmena acrea larvae infected per os usually die between 10 and $12 \mathrm{~d}$ post-infection (King et al., 1998). One report indicates that first-instar Melanoplus sanguinipes larvae succumb after $2 \mathrm{~d}$ by the $M$. sanguinipes EPV (Woods et al., 1992). Another study shows that the infected Chironomus attenuates and Goeldichronomus holoprasenus larvae may take a considerable time, up to $8 \mathrm{wk}$ die (Huger et al., 1970).

In this study, the maximum infection (93.3\%) occurred when $7.5 \times 10^{6}$ spheroids $/ \mathrm{ml}$ were used (Table 2). The insecticidal activities of the rest of the samples were $80 \%$ with $1.5 \times 10^{4}$ and $36.6 \%$ with $1 \times 10^{2}$ spheroids $/ \mathrm{ml}$ on the larvae of $M$. melolontha. We recorded that there were significant changes in the mortality depending on the number of spheroids. Our results indicate that the $M$. melolontha EPV Turkish isolate may be valuable as biological control agent against the M. melolontha pest. Therefore, this virus is a possible candidate for biological control studies in the future. However, further studies will be necessary to improve the infectivity of this virus.

\section{Effect of temperature on MmEPV infection}

The rate of development of viruses in insects depends on the temperature: the disease develops
Table 2. Mortality of M. melolontha larvae inoculated with different concentrations of MmEPV at the third-instar stage

\begin{tabular}{cccc}
\hline $\begin{array}{c}\text { Number of } \\
\text { spheroids/ml }\end{array}$ & $\begin{array}{c}\text { Number of } \\
\text { larvae in test }\end{array}$ & $\begin{array}{c}\text { Number of } \\
\text { dead larvae }\end{array}$ & $\begin{array}{c}\text { Corrected \% } \\
\text { mortality } \\
\text { (Mean } \pm \text { S.D. })\end{array}$ \\
\hline 0 (Control) & 30 & 0 & 0 \\
$7.5 \times 10^{6}$ & 30 & 28 & $93.3 \pm 4.2$ \\
$1.5 \times 10^{4}$ & 30 & 24 & $80 \pm 2.8$ \\
$1 \times 10^{2}$ & 30 & 11 & $36.6 \pm 2.2$ \\
\hline
\end{tabular}

Table 3. The effect of temperature at infection on the mortality of M. melolontha larvae inoculated with $7.5 \times 10^{6}$ spheroids/ml of MmEPV

\begin{tabular}{cc}
\hline $\begin{array}{c}\text { Temperature } \\
\left({ }^{\circ} \mathrm{C}\right)\end{array}$ & $\begin{array}{c}\text { Corrected \% mortality } \\
(\text { Mean } \pm \text { S.D. })\end{array}$ \\
\hline 20 & $73.3 \pm 2.2$ \\
22 & $76.6 \pm 2.7$ \\
25 & $93.3 \pm 4.2$ \\
28 & $86.6 \pm 3.8$ \\
30 & $83.3 \pm 3.2$ \\
\hline
\end{tabular}

more effectively at higher temperatures (Krieg, 1955). To determine the optimum temperature for the infection of MmEPV, $7.5 \times 10^{6}$ spheroids $/ \mathrm{ml}$ MmEPV was applied to third-instar M. melolontha larvae at $20,22,25,28$ and $30^{\circ} \mathrm{C}$. The highest infection rate was observed at $25^{\circ} \mathrm{C}$ (Table 3 ). Since the optimum growth temperature of the host was about $25^{\circ} \mathrm{C}$, it is expected that the optimum temperature for infection of $\mathrm{MmEPV}$ is also $25^{\circ} \mathrm{C}$. Hurpin (1968) investigated the number of dead and diseased larvae and stained the smears of hemolymph to determine the MmEPV infection over a 2 wk period. He also tested the effect of temperature on the infection of MmEPV. The results show that temperature acts not only on the growth of the host, but also on the infectivity of MmEPV. According to Hurpin (1968), the optimum conditions for the infectivity of the French isolate of MmEPV is third instar larvae and at $25^{\circ} \mathrm{C}$.

\section{Horizontal infection of MmEPV}

Since the number of the infected larvae increased up to 39 , it is obvious that there was a horizontal infection among the larval population. The results show that the horizontal infection of MmEPV was $36.6 \%$ in the populations of $M$. melolontha from Trabzon, Turkey (Fig. 3). Our ob- 


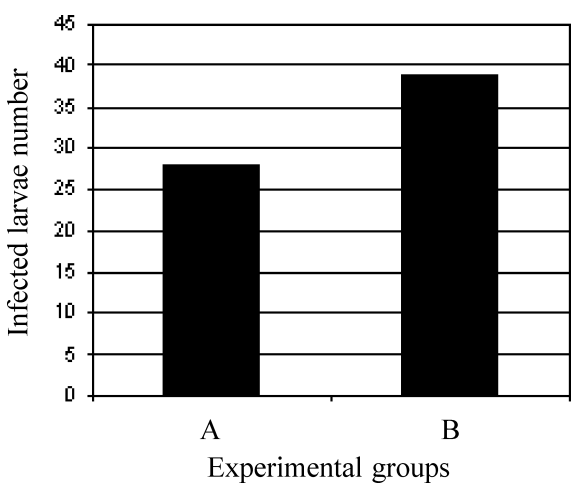

Fig. 3. Horizontal infection of MmEPV. Thirty $M$. melolontha larvae were fed MmEPV Turkish isolate-contaminated (A, B) diet. After $7 \mathrm{~d}$, insects were transferred onto fresh diet. At this time, 30 healthy larvae were added into group B. Mortality was observed up to $40 \mathrm{~d}$.

servation indicates that horizontal infection occurred when larvae fed on the pieces of tissue of the infected M. melolontha larvae. However, other possibilities of transmission should not be excluded at this stage.

The temperature in the Black Sea region of Turkey is approximately $23-25^{\circ} \mathrm{C}$ in early spring and early autumn (especially in April and September). Our results show that the proportion of EPV infection increased in these months. At these times, when insects were very hazardous on hazelnuts, the MmEPVs were very effective on the larvae of $M$. melolontha. Especially, the field evaluation times should be in spring or autumn in view of the temperature and humidity of the soil of this region. From an ecological standpoint, this is important for M. melolontha, the larvae of which live in soils where the temperature is usually $20-25^{\circ} \mathrm{C}$.

The extracted scarab virus has microscopical, pathological, and molecular properties that are characteristic of the EPVs (Arif, 1991, 1995). This study represents the first report of an EPV from a coleopteran host and the first record of an EPV disease in Turkey. Although several EPV strains are isolated from Scarabaeidae (Glare and Jackson, 1992; King et al., 1998), there is another report of isolation of an EPV from M. melolontha (Vago, 1963 ) in nature. The Turkish isolate is the second isolate of $M$. melolontha EPV in the world. Our results show that the Turkish isolate of M. melolontha EPV is promising for use in the biological control of M. melolontha, which causes very serious damage to hazelnut products. It will be necessary to carry out a molecular characterization of our isolate to compare it with other EPVs.

\section{ACKNOWLEDGEMENTS}

This work was supported by the Karadeniz Technical University Research Foundation (21.111.004.4) and the T. R. Prime Ministry State Planning Organization (21.111.004.1). The authors would like to thank Dr. Basil Arif for providing the CfEPV fusolin gene and Dr. Mustafa Yaman for help with the TEM study.

\section{REFERENCES}

Arif, B. M. (1991) The entomopoxviruses. In Viruses of Invertebrates (E. Kurstak ed.). Marcel Dekker, New York, pp. 179-195.

Arif, B. M. (1995) Recent advances in the molecular biology of entomopoxviruses. J. Gen. Virol. 76: 1-13.

Bergoin, M., G. Devauchelle and C. Vago (1969) Electron microscopy study of the pox-like virus of Melolontha melolontha L. (Coleoptera: Scarabaeidae). Arch. Ges. Virusforsch. 28: 285-302.

Bergoin, M., G. Devauchelle and C. Vago (1971) Electron microscopy study of Melolontha poxvirus: the fine structure of occluded virions. Virology 43: 453-467.

Bergoin, M., J. C. Veyrunes and R. Scalla (1970) Isolation and amino acid composition of the inclusions of Melolontha melolontha poxvirus. Virology 40: 760-763.

Bilimoria, S. L. (1991) The biology of nuclear polyhedrosis viruses. In Viruses of Invertebrates (E. Kurstak, ed.). Marcel Dekker, New York, pp. 1-72.

Evans, H. and M. Shapiro (1997) Viruses. In Manual of Techniques in Insect Pathology (A. L. Lawrence ed.). Academic Press, London, pp. 17-53.

Gauthier, L., F. Cousserans, J. C. Veyrunes and M. Bergoin (1995) The Melolontha melolontha entomopoxvirus (MmEPV) fusolin is related to fusolins of lepidopteran EPVs and to the $37 \mathrm{~K}$ baculovirus glycoprotein. Virology 208: 427-436.

Glare, T. R. and T. A. Jackson (1992) Use of Pathogens in Scarab Management. Intercept Ltd., Hampshire, England. 296 pp.

Goodwin, R. H., R. J. Milner and C. D. Beaton (1991) Entomopoxvirinae. In Atlas of Invertebrate Viruses (J. R. Adams and J. R. Bonami eds.). CRC Press, Boca Raton, Florida, pp. 259-285.

Granados, R. R. (1973) Insect poxviruses: pathology, morphology and development. Misc. Publ. Entomol. Soc. Am. 9: 73-94.

Hernandez-Crespo, P., J. C. Veyrunes, F. Cousserans and M. Bergoin (2000) The spheroidin of an entomopoxvirus isolated from the grasshopper Anacridium aegyptium (AaEPV) shares low homology with spheroidins from lepidopteran or coleopteran EPVs. Virus Res. 67: 203-213.

Huger, A. M., A. Krieg, P. Emschermann and P. Götz (1970) Further studies on Polypoxvirus chironomi, an insect virus of the pox group isolated from the midge Chironomus luridus. J. Invertebr. Pathol. 15: 253-261. 
Hukuhara, T. and J. R. Bonami (1991) Reoviridae. In Atlas of Invertebrate Viruses (J. R. Adams and J. R. Bonami, eds.). CRC Press, Boca Raton, Florida, pp. 394-430.

Hurpin, B. (1968) The influence of temperature and larval stage on certain diseases of M. melolontha. J. Invertebr. Pathol. 10: 252-262.

Jaeger, B. and W. H. R. Langridge (1984) Infection of Locusta migratoria with entomopoxviruses from Arphia conspersa and Melanoplus sanguinipes grasshoppers. J. Invertebr. Pathol. 43: 374-382.

King, L. A., N. Wilkinson, D. P. Miller and S. A. Marlow (1998) Entomopoxvirus. In The Insect Viruses (L. K. Miller and L. A. Ball eds.). Plenum Publishing Corporation, New York, pp. 1-25.

Krieg, A. (1955) Untersuchungen uber die polyedrose von Neodiprion sertifer (Geoffr.). Arch. Ges. Virusforsch. 6: 163-174 (in German).

Lipa, J. J., H. K. Aldebis, E. Vargas-Osuna, P. Caballero, C. Santiago-Alvarez and P. Hernandez-Crespo (1994) Occurrence, biological activity, and host range of Entomopoxvirus B from Ocnogyna baetica (Lepidoptera: Arctiidae). J. Invertebr. Pathol. 63: 130-134.

Milner, R. J. and G. G. Lutton (1975) The pathogenicity of an entomopoxvirus from Othnonius batesi (Col.: Scarabaeidae) and its possible use a control agent. Entomophaga 20: 213-220.
Radek, R. and P. Fabel (2000) A new entomopoxvirus from cockroach: light and electron microscopy. J. Invertebr. Pathol. 75: 19-27.

Sanz, P., J. C. Veyrunes, F. Cousserans and M. Bergoin (1994) Cloning and sequencing of the spherulin gene, the occlusion body major polypeptide of the Melolontha melolontha entomopoxvirus (MmEPV). Virology 202: 449-457.

Sezen, K. (2004) Determination of viruses from coleopteran pests of hazelnut and the potential usage as biological control agent. PhD. thesis, Department of Biology, Graduate School of Natural and Applied Sciences, Karadeniz Technical University, Trabzon, Turkey. 70 pp.

Vago, C. (1963) A new type of insect virus. J. Insect Pathol. 5: 275-276.

Vago, C. and M. Bergoin (1968) Viruses of invertebrates. Adv. Virus Res. 13: 247-303.

Wegensteiner, R. and J. Weiser (1995) A new entomopoxvirus in the bark beetle Ips typographus (Coleoptera: Scolytidae). J. Invertebr. Pathol. 65: 203-205.

Woods, S. A., D. A. Streett and J. E. Henry (1992) The temporal pattern of mortality from an entomopoxvirus and strategies for control of the migratory grasshopper (Melanoplus sanguinipes F.). J. Invertebr. Pathol. 60: 33-39. 